\title{
PREVALENCE OF AEROMONAS HYDROPHILA AND YERSINLA ENTEROCOLITICA IN SOME SEAFOOD'S SOLD IN SHARKIA GOVERNORATE MARKETS AND THE EFFECTS OF HEAT TREATMENTS ON THEIR VIABILITIES
}

\author{
Salah El-Dien, W. M.; Enas, M. Sami; \\ Hanan, M. T. El-Lawendi and Saleh, M.A*. \\ Food Hyglene Dept. and Mierobiology \\ Dept." Animal Health Regearch Institule (Zagazlg Provlncial Lab.), Egypt.
}

\begin{abstract}
A total of 120 samples of fresh mullet. frozen tilapia fillet and chilled shrimps 140 each) were collected from the markets of Sharkia Governorate for surveying the organisms of Aeromonas hydrophila and Yersinla enterocalitica in their flesh. Aeromonas organisms. Were detected in 34 (85\%), 12 (30\%) and 28 (70\%) of samples, with the mean levels of total colony count were 4.9 $1 \pm 0.247,4.383 \pm 0.463$ and $4.44 \pm 0.125 \mathrm{log} \mathrm{CFU} / \mathrm{g}$ respectively. Such organisins were identified as Aeromonas hydrophila, $A$. caviae and A. sobria with acommen prevalence for A. hydrophila.

Whilst Yersinia organisms recogrized in 26 (65\%), 6 (15\%) and 20 (50\%) samples of the examtned samples, with the mean value of a total colony count of $5.142 \pm 0.353$, $4.284 \pm 0.671$ and $3.06 \pm 0.221 \log \mathrm{CFU} / \mathrm{g}$ respectively. These organisms were identfied into. Y. enteracolitica, Y. fredrediksenii, Y. Intermedia and Y. Kristensenil with a highest prevalence for Y. enterocolitica.

The present investigation revealed also that both of $A$. hydrophila and $Y$. enterocolitica were sensitive to heat treatment. Thus, good ripenting of sea foods is adequate to control of these microorganisms.
\end{abstract}

\section{INTRODUCTION}

FIsh and other aquatic foods are important sources of high quality, easlly digestible protein and often low fat (Salem, 2003). Moreover, it contained high levels of some essential minerals and trace elements as phosphoris, lodine and zinc. Because these foods have galned popularity among international consumers; thus, the studying of these microblolog- ical contaminations is significant for the public health of consumer.

Aeromonas hydrophila is a commion contaminant of ilsh and seafood. They also are ubiquitous in the water environment (Hänninen et al, 1997). It oceurs widely in coastal waters aud wastewater. The prevalence of Aeromonas spp. In the aquatic env- 
ronment has been reeognized as a potentual health risk, and some countrles have adopted aeromonas eounts as an additional indicator of water quallty (Kong et al, 1989). Moreovel:, Aeromonas hydrophila is a psyehrotrophje spoilage bacterium and potential pathogen which has been Isolated from a varlety of refrigerated foods of animal origin as fish, shrimps and other fish products (James et a, 1987). From the public health point of view, there is now evidence that some stralns of Aeromonas species are enteropathogensi. Such strains possess virulence properties; such as the ability to producc entcrotoxinsi. cytotoxins, haemolysins and/or the abllity to invade cpithelial cells. Strains with thcse properties are common contaminants of drinking water and a wide range of loods. Contact or consumption of contaminated water, especially in summer, is a major risk factor in Aeromonas-assoclated gastroenteritus (Kirov, 1993).

Yersinia cnterocolitica is a foodbome pathogen and it contaminates refrigerator foods due to its psychrotrophic nature (Vish. nubhatla et al, 2000). So; fish, shrimps and fish products which often sold in chilled or frozen condition may be exposed to contamination with Yersinla enterocolitica which responsible for the most human illnesscs by Yersinia spp. Infection with Y. enteroeolitica can cause a vartety of symptoms depending on the age of the pcrson infeeted. Infection with $Y$. enterocolittca occurs most often in young children. Common symptoms in children are fever, abdominal pain, and dlarrhea., wbich is often bloody. Symptoms typically develop 4 to 7 days after exposure and may last 1 to 3 weeks or longer. In older children and adults, right-sided abdominal pain and lever may be the predominant symptoms, and may be confused with appendicitss. In a small proportion of eases, complications such as skin rash, joint pains. or spread of bacterla to the blood stream can occur ( C.D.C 2009).

The aim of the present study is to detcrmine the prevalenee of Aeromonas hydrophila and Yersinla enterocolluca in some sea foods In Sharkla Govemorate and study the effect of heat treatment on their viabllttes.

\section{MATERIAL AND METHODS}

\section{Callection of samples :}

A total of 120 samples of fresh mullet. frozen ulapla fllet and chilled shrimps (40 each) were eolleeted from the markets of Sharkia Govemorate. Each sample was packaged in a sterle plastic bag. The collected samples were transferred directly to the laboratory under aseptie condition with a minimum of delay. wherein they were subjected to bacterlological examination.

\section{Determination of Aeromonas organisms} count :

The count of Aeromonas organisms was determined by using the surfaee spread platc technlque, where $10 \mathrm{gm}$ from each sample were aseptically transferred to $90 \mathrm{ml}$ of peptone water $0.1 \%$ and blended for $2 \mathrm{~min}$. The prepared samples were serlally diluted up to 10-6 using $0.1 \%$ peptone water, and the count was eartied out on the aforementloned dllutions as rccommended (Pajumbo et al. 1985) using MacConkey manitol ampicillin agar. The number of colonies which showed red color in a eountable plate was enumerated as Aeromonas organisms. 
Isolation of Aeromonas specles:

a- Enrichment procedure: This was done according to the technique was adopted (Palumbo et al. 1989).

b- Isolation and identification techniques: The technlque adopted was that used as prevlously described (Okrend et al, 1887) and (Koneman et al, 1994) .

Icolation and Identification of Yersinia enterocolltica

a- Eartchment procedure

$1 \mathrm{ml}$ of rinse solution of fish meat was placed aseptically into enrichment broth (Trypticase soy broth) and incubated at $37^{\circ} \mathrm{C}$ for 24 hours (Greenwood and Hooper 1989).

\section{b- Igolation technique}

A looplul of the Ineubated broth was streaked directly onto Cefsuldin Irgasan Novoubiocin (CIN) as prevlously described (Schtemann, D. A 1979) and then incubated at $37^{\circ} \mathrm{C}$ for 24 hours. The presumptue colonies were identfled (Schlemann, and DevenIsh 1982).

\section{Bacterial culture (inocnium)}

The culture of microorganism was maintalned on braln heart infusion agar (BHI) slants Inoculated was Incubated into $\mathrm{BHI}$ broth and inoculated overnight at $37^{\circ} \mathrm{C}$. Serial dilution of fresh culture was carried out onto $0.1 \%$ peptone water to obtain a target lcvel of microorganlsm of $107 \mathrm{CFU} / \mathrm{ml}$ when $0.1 \mathrm{ml}$ of inoculum was applled to each side of product.

\section{Sample Inoculation}

Sixty negative sub samples of both Aero- monas hydrophild and Yearsinla enterocolitica resulted from insh fillet meat samples were grounded. Thirty ground samples were mixed w1th Aeromonas hydrophila and another 30 yround samples were mixed with Yersinia enterocolltiea at a ratio of 1 ml of eulture per $100 \mathrm{gm}$ of meat sample. The Inoculation level for the both examined bacterla was about 107 CFU /g (7 log). Inoculated fish meat samples were kept at $4^{\circ} \mathrm{C}$ for $30 \mathrm{~m} / \mathrm{n}$ to allow bacterlal cells attachment to meat.

\section{Heat treatment:}

Thirty of the inoculated samples with Aeromonas hydrophlia were treated by submersion in thermostatically - controlled water bath at $30-50^{\circ} \mathrm{C}, 50-70^{\circ} \mathrm{C}$ and $70-90^{\circ} \mathrm{C}$ for one minute 110 samples for each temperature). Another 30 inoculated samples with Yersinla entcrocolltica were exposed to the same heat treatments as previously mentioned with Aeromonas hydrophlla. Nfter the conducting of the heat treatments. the examined samples were cooled immediately in an ice water bath. All samples were tested microblologleally for obtaining the count of Aeromonas hydrophlla and Yersinla enterocolitica aster the mentloned heal treatment.

\section{RESULTS AND DISCUSSION}

Results achieved In Table (1) revealed that Aeromonas organisms. were detected in 34 (85\%). 12 (30\%) and 28 (70\%) of mullet. frozen tilapla fillet and shrmp samples with mean logarithmic levels $4.91 \pm 0.247 .4 .383$ \pm 0.463 and $4.44 \pm 0.125 \mathrm{log} / \mathrm{g}$ respectively. These results were higher in both the incidence and count than those prevlously reported (Abd EI- Daym 1999) and (ADo - EL-Alla 2000) On the other hand, another study in 
Finland detected higher Incidence of Aeromonas spp. than those in the present study in Ish and shrimps $193 \%$ and $100 \%$, respectlvely) (Hynninen et al, 1987) .

Table (2) showed that three strains of Aeromonas Spp. were detected. A. hydrophyla was detected in 30,10 and 20 samples of mullet, frozen tlapia flllet and shrimp respecuvely, the same examined sea foods contained A. caviae in 3, 1 and 5 samples respectlvely. Meanwhile, A. sobria was detected in L, 1 and 3 of the previously mentioned samples respectively. It is evident from these data that A. hydrophyla was the most eormon specles from the examined samples followed by $A$. cavlae and A. sobria, this result eolncided wth those obtained in Egypt (Abo - EL Alla 2000).

Concerning the effects of heat treatment on the Aeromonas Spp. count. Table 3 revealed that the temperature range from $30.50^{\circ} \mathrm{C}$ for 1 minute redueed the Aeromonas Spp. count from $7 \mathrm{log} /$ CFU (the initlal count) to 4.709 log/ CrU, whlle: $50-70^{\circ} \mathrm{C}$ for one minute redueed the initial number to $2.269 \log / \mathrm{CFU}$. Furthemore, the Initjal number of the lested Inicroorganism reached to zero when expossed to $70.90^{\circ} \mathrm{C}$ for one minute. Thus, the abtained results revealed that the Aeromonas Spp. was highly sensitive to thermal treatment. Our results colnctded with another study recorded that Aeromonas Spp. was obvously sensitive to heat treatment than $E$ coll 0157 H7. Staphylococcus aureus, and Salunonella typhimurium and it was kdlled within 2 minutes at $55^{\circ} \mathrm{C}$. (Nishlleawa et al, 1993).

Regarding Yersinia spp.. Table (4) showed that it was detected in $26(65 \%), 6(15 \%)$ and $20(50 \%)$ of the examined mullet fish. Irozen tlapla fllet and shrimp samples respectively, with the mean total colony counts of $5.142 \pm$ $0.353 .4 .284 \pm 0.671$ and $3.06 \pm 0.221 \log /$ CFU respectively in the same menuoned sea foods. These incldences were higher than those detected in meat products in Egypt (Saleh, and Salah El- Dlen, 2005). while; another Egyptlan study could not be detect Yersinla spp. In all the examined flsh samples in both rural and urban areas (Sollman et al. 2002). On contrary, our ngures reeoded lower incidence of Yersinia spp. than those reported in Rish In Indla (Khare et al, 1896).

Table (5) showed that four stralns of Yersinia spp. were detected in the examined samples. Y. enterocolitica was isolated from 14,5 and 15 samples of mullet fish, frozen tilapia flliet and shrimp respeetively. Y. fredrediksenll was detected in 4.1 and 3 samples of the mentioned examined sea foods respectively. On the other hand, Y. Intermedla was found in 5 mullet lish and 2 shrinp samples. while: Y. Kristensenll was detected only in 3 mullet samples. The obtained results showed that. $Y$. enterocolitica was the most predominant isolate, thls result agreed with another Egyptian study (Bahout. and Moustafa, 2004). On contrast, the most predominant isolates in the examined nsh samples in a prevously Indian study were $Y$. intermedia and $Y$. pestis (khare et al, 1996).

Table (6) Indlcates that the temperature ranged from $30-50^{\circ} \mathrm{C}$ for 1 minute reduced the total count of $Y$. enterocolltea from $7 \mathrm{log} /$ CFU (the Inital eount) to $4.414 \mathrm{log} / \mathrm{CFU}$. Also, the exposure to $50-70^{\circ} \mathrm{C}$ for 1 minute 
reduced the count of the examined microor. ganism from $7 \mathrm{log} / \mathrm{CFU}$ to $3.255 \mathrm{log} / \mathrm{CFU}$. Meanwhlle, the exposure to temperature ranged between $70-90^{\circ} \mathrm{C}$ for 1 minute was suffielent to reduce the inftial number of $Y$. enterocolitica from $7 \log / C F L$ to zero. This finding revcaled a relatuely high sensituvity of Y. enterocolitica to heat treatment, and it was highly expected duc to the psychotropic nature of this microorganism. The obtained results coinclded with those reported in Spain (Pagán et al, 1986) and U.S.A. (Porto-Fett et al, 2009).

Conccrning the fleness of the examined sea foods for the human consumption, Aerono nas Spp. and Yersinia spp. were not Judged by "Egyptan Organization for Standardization and Quallty Conirol" (EOsgC 2005).

From alorementioned results, it is evdent that the examined sea foods suffered from relativcly high Incidence and levels of both Aeromonas spp. and Yersinla spp. cspeclally A. hydrophila and $Y$. enterocolitica. These results explalned by lack of hyglenic supervlslon during handing and transformation of these sea foods. Moreover, because the exam-
Ined sea foods werc displayed in frozen or chllling state, the psychotroplc character of the tested microorganisms plays an important role to elevate its incidence and count (Vighnubhatla et al, 2000) and (Abo - EL Alla 2000). Fortunately. the obtained results showed that both A. hydrophla and Y. enterocolltica were sensitive to heat treatment. Thls result can threw a light upon the suggested solutions of food contamination problem with these mentioned microorganisms.

\section{CONCLUSION AND RECOMMENDATTONS}

1 - Maintaining clean water supply and In struments used in lce produetion for chilling of sea foors.

2- Transportation, storage and displaying ol sea foods should be under hyglenic procedures.

3- Continuous monitoring of the hyglenic state of different sea foods is highly recommended.

4- Sea foods must be exposed to adequate temperature during its ripening to destruct the mlcroorganisms under the present investlgation. 
Salah EL-Dien, W. M. et al...

Table (1): Occurrence and intensity of Aeromunas urganisms in surveyed seafood samples. ( $n^{\star}=40$ each)

\begin{tabular}{|l|c|c|c|c|}
\hline Type of samples & $\begin{array}{c}\text { Numbers and } \\
\text { percentages of } \\
\text { Aeromonus- } \\
\text { contaminated } \\
\text { samples }\end{array}$ & \multicolumn{3}{|c|}{$\begin{array}{c}\text { Logarithmic levels of Aeromonas } \\
\text { organisms (Log) in contaminated } \\
\text { samples }\end{array}$} \\
\cline { 2 - 5 } & $34(85 \%)$ & Min. & Max. & Mean \pm S.E. \\
\hline Mullet & $12(30 \%)$ & 1.973 & 6.857 & $4.91 \pm 0.247$ \\
\hline Frozen tilapia fillet & $28(70 \%)$ & 3.437 & 5.623 & $4.44 \pm 0.125$ \\
\hline Shrimp & & &
\end{tabular}

$n^{*}=$ number of examined samples.

Table (2): Serotyping of Aeromonus spp in the examined samples ( $n=40$ for each).

\begin{tabular}{|c|c|c|c|c|}
\hline Type of samples & $\begin{array}{c}\text { No. of total } \\
\text { isolated strains }\end{array}$ & A. hydrophyla & A. caviae & A. sobria \\
\hline Mullet & 34 & 30 & 3 & 1 \\
\hline Frozen tilapia fillet & 12 & 10 & 1 & 1 \\
\hline Shrimp & 28 & 20 & 5 & 3 \\
\hline Total (120 & $\begin{array}{c}74 \text { strains } \\
\text { samples) }\end{array}$ & $\begin{array}{c}60 \text { strain } \\
(100 \%)\end{array}$ & $\begin{array}{c}9 \text { strains } \\
(12.08)\end{array}$ & $\begin{array}{c}9 \text { strains } \\
(12.16 \%)\end{array}$ \\
\hline
\end{tabular}

Table (3): Effects of 3 heat treatments on the mean logarifhmic counts \pm S.E. of Aeromonas hydrophila in fish fillet (n=10 for each treatment).

\begin{tabular}{|c|c|c|c|}
\hline \multirow[b]{2}{*}{$\begin{array}{l}\text { Initial population of } \\
\text { Aeromonas hydrophila }\end{array}$} & \multicolumn{3}{|c|}{$\begin{array}{l}\text { mean logarithmic levels of Aeromonas hydrophila } \\
\qquad(\log / \mathrm{CFU})\end{array}$} \\
\hline & $\begin{array}{l}\text { After heating } \\
\text { at } 30-50^{\circ} \mathrm{C} \\
\text { for one min. }\end{array}$ & $\begin{array}{l}\text { After heating at } \\
50-70{ }^{\circ} \mathrm{C} \\
\text { for one min. }\end{array}$ & $\begin{array}{c}\text { After beating at } \\
70-90^{\circ} \mathrm{C} \\
\text { for one min }\end{array}$ \\
\hline $7 \log / g$ & $4.709 \mathrm{log} / \mathrm{g}$ & $2.269 \mathrm{log} / \mathrm{g}$ & $0.0 \mathrm{log} / \mathrm{g}$ \\
\hline
\end{tabular}


Salah El-Dien, W. M. et al...

Table (4): Occurrence and intensity of Yersinia organisms in surveyed seafood samples, $\left(n^{*}=40\right.$ each $)$

\begin{tabular}{|c|c|c|c|c|}
\hline \multirow[t]{2}{*}{ Type of samples } & \multirow{2}{*}{$\begin{array}{l}\text { Numbers and } \\
\text { percentages of } \\
\text { Yersinia- } \\
\text { contaminated } \\
\text { samples }\end{array}$} & \multicolumn{3}{|c|}{$\begin{array}{l}\text { Logarithmic levels of Yersinia } \\
\text { organisms (Log) in contaminated } \\
\text { samples }\end{array}$} \\
\hline & & Min. & Max. & Megn \pm S.E. \\
\hline Mullet & $26(65 \%)$ & 2.3 & 7.6 & $5.142 \pm 0.353$ \\
\hline Frozen tilapia fillet & $6(15 \%)$ & 1.079 & 5.434 & $4.284 \pm 0.671$ \\
\hline Shrimp & $20(50)$ & 1.778 & 4.698 & $3.06 \pm 0.221$ \\
\hline
\end{tabular}

$n^{*}=$ number of examined samples.

Table (5): Serotyping of Yersinia Spp. In the examined samples ( $n=40$ for each).

\begin{tabular}{|c|c|c|c|c|c|}
\hline $\begin{array}{c}\text { Type of } \\
\text { samples }\end{array}$ & $\begin{array}{c}\text { No. of total } \\
\text { isolated } \\
\text { strains }\end{array}$ & $\begin{array}{c}\text { Y. } \\
\text { enterocolizica }\end{array}$ & $\begin{array}{c}\text { Y. } \\
\text { fredrediksenii }\end{array}$ & $\begin{array}{c}\text { Y. } \\
\text { Imrermedia }\end{array}$ & $\begin{array}{c}Y . \\
\text { Kristensenii }\end{array}$ \\
\hline Mullet & 26 & 14 & 4 & 5 & 3 \\
\hline $\begin{array}{c}\text { Frozen } \\
\text { tilapia fillet }\end{array}$ & 6 & 5 & 1 & 0.0 & 0.0 \\
\hline Shrimp & 20 & 15 & 3 & 2 & 0.0 \\
\hline $\begin{array}{c}\text { Total (120 } \\
\text { samples) }\end{array}$ & $\begin{array}{c}\mathbf{5 2} \text { strains } \\
(\mathbf{1 0 0} \%)\end{array}$ & $\begin{array}{c}\mathbf{3 4} \text { strains } \\
(\mathbf{6 5 . 3 8 \% )}\end{array}$ & $\begin{array}{c}\mathbf{8} \text { strains } \\
(\mathbf{1 5 . 3 8 \% )}\end{array}$ & $\begin{array}{c}\mathbf{7} \text { strains } \\
(\mathbf{1 3 . 4 6 \% )}\end{array}$ & $\begin{array}{c}\mathbf{3} \text { strains } \\
(\mathbf{5 . 7 7 \%})\end{array}$ \\
\hline
\end{tabular}

Table (6): Effects of 3 heat treatments on the mean logarithmic counts \pm S.E. of Yersinia enterocolitica in fish fillet $(n=10$ for each treatment).

\begin{tabular}{|c|c|c|c|}
\hline \multirow{2}{*}{$\begin{array}{l}\text { Initial } \\
\text { population of } \\
\text { Yersinia } \\
\text { enterocolitica }\end{array}$} & \multicolumn{3}{|c|}{ Mean logarithmic levels of Yersinia enterocolitica (log/CFU) } \\
\hline & $\begin{array}{l}\text { After heating } \\
\text { at } 30-50{ }^{\circ} \mathrm{C} \text { for } \\
\text { one min. }\end{array}$ & $\begin{array}{l}\text { After heating at } \\
50-70^{\circ} \mathrm{C} \\
\text { for one min. }\end{array}$ & $\begin{array}{c}\text { After heating at } \overline{70} \text { - } \\
90^{\circ} \mathrm{C} \\
\text { for one min }\end{array}$ \\
\hline $7 \log / g$ & $4.414 \log / \mathrm{g}$ & $3.255 \mathrm{log} / \mathrm{g}$ & $0.0 \log / g$ \\
\hline
\end{tabular}




\section{REFERENCES}

Abd El- Daym, W. F. A. (1889) : Microblological aspects of smoked inshes at retall outlets. Master D. Thesis, Vet. Med. Sci. (Meat Hyglene) Zagazig Univ.

Abo - EL-Alla (2000) : Studies on Aerornonas hydrophlla in fresh water fish (Oreochromis niloucus and Labeo Nlloticus) and smoked flshes (Herrings) in Assiut Governorate.

Ahmed, M. Sh.: Zaltoun, A M. and All. H. S. (1991) : Motile Aeromonas septicaejnia (MAS) in Mormyrus Kannume at Assiut Govemorate. Assiut Vet. Med. J., 25: 145-150.

Bahout, A A and Moustafa, A $H$. (2004) : Occurrence of Yersinta specics in raw and pasteurlzed milk in Dakahlia Governorate. Assiut Vet. Med. J, Vol. 50 No.101: 5763.

Bastawrows, A F. and Mohammed, A. A (1999) : Some microblological investlgations on Aeromonas hydrophlla group in Oreochromis nillotlcus and Clarlas lazera in Asslut Governorate. Assiut Vet. Med. J.,40: 197-21)6.

C. D. C. Central of disease control and prevention (2009) : Yersinla enterocolltica. On web site: http.//www.cdc.gov/index.hIm

Egyptian Organization for standardization and gually control (2005) : The permissible limits for fish. 1-889/2005.

Greenwood, M. H. and Hooper, W. L. (1989) : Improved methods for the isolation of Yersinia specles from milk and foods. Food
Microblol., 41(3): 99-104.

Hannluen, M, L.; Oivanen, P. and Hirvelk-kogk, V. 1. (1967) : Aeromonas species in flsh, fish-eggs, shrimp and freshwater. Intern. J. of Food Mlcroblol. 34(1) : 17-26.

James, $S$ D.: Sheldon, Brtan W. and Foegeding. P. M. (1997) : Thermal resistance of Aeromonas hydrophtla in liquid whole egg. J. of Food Prot. 60(3): 231-236.

Khare S. 8.; Kamat, A S.; Doctor T. R. Nadr P. M. (1806) : Incidenee of Yersinia enterocolttica and related species in some fish, meat and meal producls in lndra. Journal of the science of lood and agriculture vol. 72 , (2)، pp. 187-195.

Rirov, S. M. (1993) : The public health significance of Aeromonas spp. in loods. Intem. J. of Food Microbiol. 20( 4): 179-198.

Koneman, E. W.: Allen, B. D.; Janda, W. M.; Schreckenberger, P. C. and Whn, W. C. Jr. [1994) : Interoduction to Dlagnostic Microblology J.B. Lippincott Company Pp. 117. 123.

Kong, R. Y. C. A: Pelling, C. L. and R. B. S. Wu (1999) : Identufication of ollgonu cleoude primers targeted at the 165-235 rDNA intergenic spacers for genus- and specles-specific detectlon of aeromonads. Marinc Pollution Bulletın 38(9): 802-808

Erend, A J. G.; Rose, B. E. and Bennett. B. (1987) : Incidence and loxigentcity of Aeromonas species in retalled poultry, beef and pork. J. Food Port.. 50: 509-513. 
Nighilsawa, Y.: Ogasawara, J. and Kimure. T, (1993) : Heat and acid sensitivity of motile Aeromonas: a comparison with uther food-polsoning bacterla. International foumal of food microbiology. 18(4):271-8.

Pegán, R.; Mañas, P.: Raso, J.; and Sala Trepat. F.J.(1098): Heat resistanee of Yers1 nla enterocolitica grown at different temperatures and heated in different media. Intern. J. of Food Mlcroblol. 47(1-2):59 -66.

Palumbo. S. A: Maxino. F.; Willams, A. C.: Buchananaaon, R. L. and Thayer, D. W. (1985) : Starch - ampiclllin agar for the quantstative detection of Acromonas hydrophlla. Appl. Environ. Microblol., 50 : 1027 1030 .

Palumbo, S. A. Bencivengo, M. M.; Delcarral, F.; Wullams, A. C. and Buchanan, R. L. (1989) : Charaeterization of Aeromonas hydrophll group isolated from retalled food of animal ongin. J. Clin. Microblol. 27: 854859.

Porto-Fett. A. C.: Juneja. V. K.: Tamplin, M. L. and Luchansky, J. B. (2009) : Validation of cooking times and temperatures for therinal inactuvation of Yersinla pestls stralns KIM5 and CDC-A1 122 In liradlated ground beef. . J Food Prot. 72(3):564-71.
Saleh, M. A and Salah El-Dlen, W. $M$. (2005): Microbioluglcal studies on some meat products At Sharkja Governorate Markets. Zag. Vet. J. Vol. 33 (3): 141-151.

Salem D. A. (2003) : Survey of some environmental pollution in freshwater Rshes Asslut Governorate. Egypt. Ass. Univ. Bull. En viron. Res. Vol.6 (2): 15- 36.

Schlemann, D. A (1879) : Synthesis of a selectlve agar mcdium for $\mathrm{Y}$. enterocolitica. Canadian J. of Microblol., 25: 1298-1304.

Schlemann, D. A and Deventsh. J. A (1882) : Relationship of Hela cell Infectivity to blochemical, serological and viulence characteristics of Y. enterocolitica. Infect. Immun.. 35: 497-506.

Soliman, M. R.; Abo El-Monem, K. H. M. and Sard, S. M. (2002) : Mieroblological quality of ready to eat meat products and flsilıes in urban and rural areas. J. Egypt. Vet. Med. Ass. 62.No. 6a: 39-51.

VLshnubhatle, A: Fung, D. Y. C.; Obrat. R. D.; Hays M. P.; Nagaraja, T. G. and Food, S. J. A. (2000) : Rapled 5' Nuclease (Toq Man) Assay for detection of virulent strain oe Yersinla enteroeolitica. Appl. Environ. Micrabiol. 66 (9): 4131-4135. 
Salah El-Dien, W. M. et al...

اللاخص المريى

ملى تواجد جراثيم إيروموناس هيدروفيلا واليارسينيا انتروكلرتيكا فى بعض المأكيلات

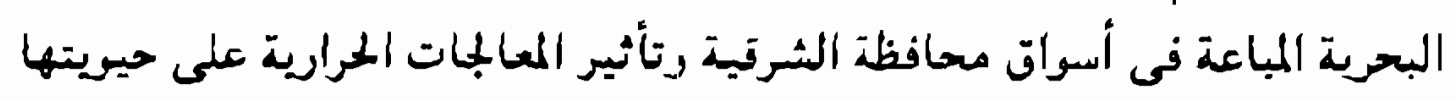

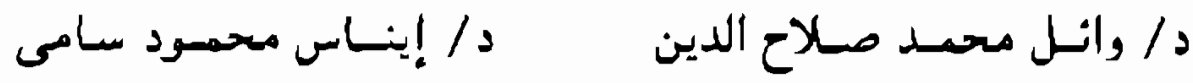

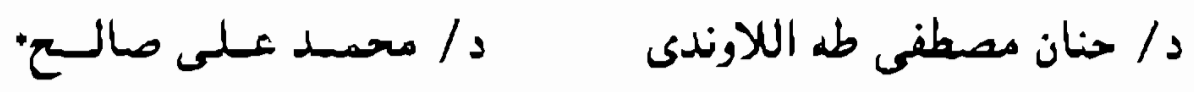

$$
\begin{aligned}
& \text { تسم صسة الأغذهة - تسم البكرديبرلوجيا" - مسد سعرث صسن الحبران (معسل الزمانيق الفرعى) }
\end{aligned}
$$

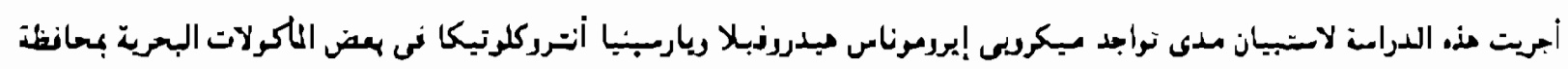

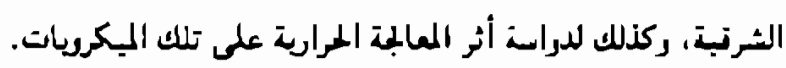

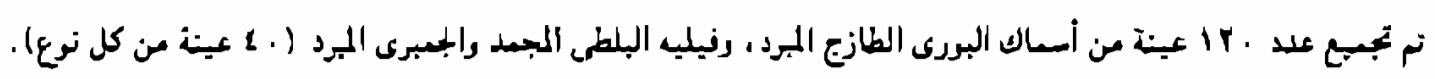

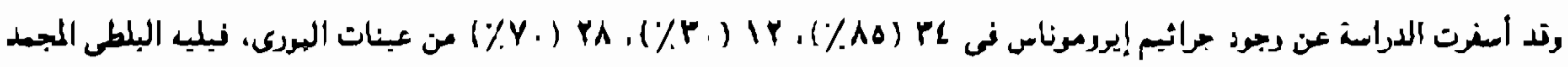

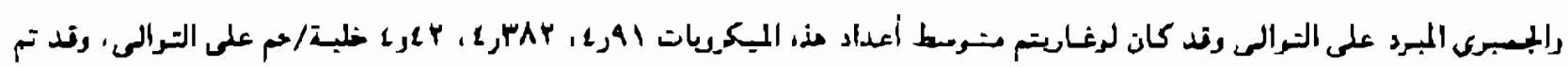

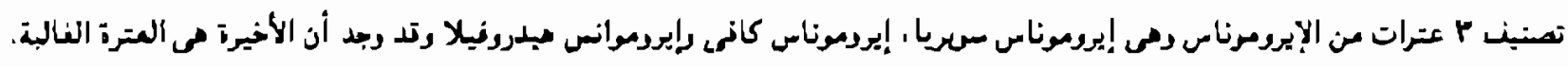

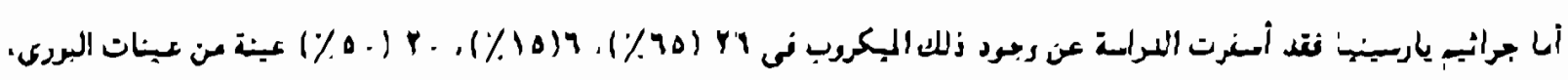

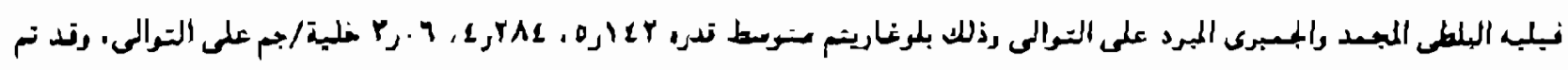

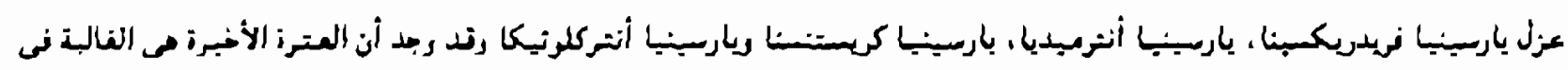
معظم العينات.

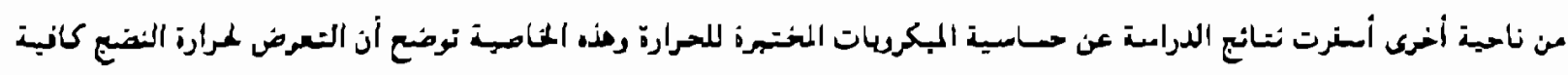

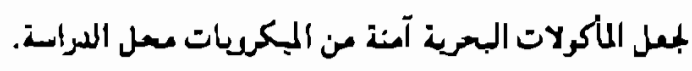

